\title{
Early Permian climate change in the Falkland Islands
}

\author{
Phil Stone $^{1}$ and Kate Horan ${ }^{2}$ \\ ${ }^{1}$ British Geological Survey, Edinburgh EH9 3LA, UK. psto@bgs.ac.uk \\ ${ }^{2}$ Department of Earth Sciences, University of Durham, Durham DH1 3LE
}

\begin{abstract}
An Early Permian glacial diamictite forms a distinctive unit within the Falkland Islands sedimentary succession and two aspects of its significance have recently been serendipitously enhanced. Fossil discoveries in exotic limestone clasts bear on palaeogeography, whilst a series of mineral-exploration borehole cores have allowed a detailed study of the sedimentary record of deglaciation that followed deposition of the diamictite. Statistical analysis of reflectance and XRF corescanning data has identified likely Milankovitch periodicities and enabled tentative time-scale modelling. The 'icehouse to greenhouse' transition appears to have spanned approximately 1.2 million years, with waning cycles of readvance superimposed on overall glacial retreat. The new results play into a long-debated geological paradox: although the Falkland Islands are now proximal to the South Atlantic coastline of South America, their geology bears an uncanny resemblance to that of the Cape Fold Belt and Karoo Basin in South Africa. This puzzled the geological pioneers, but became readily explicable when first continental drift and then plate tectonics were invoked to reconstruct the break-up of the Gondwana supercontinent - although the details remain controversial. One of the key stratigraphical correlation levels throughout the major fragments of southern Gondwana - South Africa, South America, Antarctica and Australia - is the glacigenic deposit left behind by the extensive, Late Carboniferous to Early Permian regional glaciation; in the Falkland Islands it is designated the Fitzroy Tillite Formation.
\end{abstract}

The Falkland Islands lie in the south-west part of South Atlantic Ocean, centred around $52^{\circ}$ South, $60^{\circ}$ West, and about $500 \mathrm{~km}$ east of the South American mainland. Two large islands, East and West Falkland, are surrounded by a dozen or so large subsidiary islands, and hundreds of smaller islands, rocks and reefs comprising a total land area of just over $12000 \mathrm{~km}^{2}$ (Fig. 1). The archipelago is formed mostly by sedimentary rocks ranging in age from Siluro-Devonian to Permian, with the glacigenic Fitzroy Tillite Formation forming one of the lower units within the Permian succession.

The Fitzroy Tillite Formation takes its name from the eponymous farm settlement of Fitzroy, East Falkland (Fig. 1), itself named after the captain of HMS Beagle which, in 1833 and 1834, brought the young Charles Darwin to the Falkland Islands. 
Darwin's work was the first geological investigation of the archipelago, but discovery of the strange conglomeratic diamictite had to wait until 1845, when his erstwhile shipmate (and great friend) Bartholomew Sulivan returned to continue Fitzroy's surveying in command of his own ship, HMS Philomel. Sulivan wrote to Darwin describing the accumulation of exotic pebbles and boulders that he had seen at Hill Cove, on the north coast of West Falkland (Fig. 1), but Darwin misunderstood, and thought the deposit to be a relatively recent accumulation of debris brought ashore by grounded icebergs rather than an accumulation of debris weathered from an in-situ lithology; he had previously come to a similar conclusion regarding 'ice formations' that he had observed around the coast of South America. Sulivan demurred, but there the matter rested and Darwin moved on to other things.

Sixty years after Sulivan's observations a Swedish geologist, Thore Halle, visited the Falkland Islands during the Swedish Magellanic Expedition (1907-1909) and made great progress in establishing the geological succession and structure. Amongst other things, he correctly identified the Hill Cove deposit as a glacigenic tillite and, what's more, made the correlation with the Dwyka tillites of South Africa. Additional information was then sporadically gathered over the next decades, most notably during the 1965-66 austral summer by a team from the University of California, who laid down the basis of the modern interpretation. This was refined in the mid-1990s during a comprehensive field mapping programme supervised by the British Geological Survey and sponsored by the Falkland Islands Government's Department of Mineral Resources.

\section{A geological overview}

Before looking in detail at the character and significance of the Fitzroy Tillite Formation and its associated strata, it will be helpful to place it into context within the overall geology of the Falkland Islands (Figs 1 and 2). The oldest Falkland Islands rocks are the ca 1000 million years old, granite and gneiss of the Proterozoic Cape Meredith Complex, which are restricted to a coastal outcrop on the southernmost point of West Falkland. The Proterozoic rocks are unconformably overlain by the West Falkland Group, a thick succession of fluvial to neritic and shallow marine, clastic strata ranging in age from Silurian to Devonian. The West Falkland Group underlies most of West Falkland and the northern part of East Falkland. In the southern part of East Falkland a younger succession of strata, the Lafonia Group, includes the Early Permian, glacigenic Fitzroy Tillite Formation and an overlying thick succession of Permian, deltaic and pro-delta basinal (probably lacustrine) strata. The latter were deposited in a sedimentary basin formed ahead of a developing foldand-thrust belt that concurrently deformed the Silurian to Devonian succession. All of the metamorphic and sedimentary rocks are cut by swarms of Early Jurassic and Early Cretaceous dolerite dykes. 
With the exception of the Early Cretaceous intrusive dyke swarm, the geological development of the Falkland Islands took place in the context of the Gondwanan supercontinent. Comparisons with what were then contiguous sectors of Gondwana, now preserved in South Africa, South America and Antarctica are important and correlations with South Africa have been particularly influential, with the West Falkland and Lafonia groups bearing striking similarity, respectively, to the successions of the Cape Fold Belt and Karoo Basin. Deformational histories are also similar and the interpretation of this regional association is crucial to the stillcontroversial plate tectonic history of the Falkland Islands. Recent data derived from the Fitzroy Tillite Formation has relevance to that debate.

The Early Cretaceous dykes link the onshore geology with that of offshore basins that originated through crustal extension as the South Atlantic Ocean opened following the initial break-up of Gondwana. The principal sedimentary basins around the Falklands have recently been the subject of extensive seismic surveys and a number of exploration wells have been drilled, mostly to the north of the archipelago in an archetypal failed rift. The general basin stratigraphy features a Late Jurassic and younger sedimentary succession that lies either on strata equivalent to the onshore West Falkland and Lafonia groups, or on possible Jurassic volcanic lavas.

\section{The Fitzroy Tillite Formation}

Along the north coast of West Falkland the Fitzroy Tillite Formation appears as a clast-rich but still matrix-supported diamictite (Fig. 3), with a wide range of exotic clast lithologies and with individual clasts ranging up to several metres across. It is interpreted as a terrestrial deposit, with enclosed, linear sand bodies seen at Hill Cove thought of as esker-like channel-fills. A sub-horizontal fabric seen locally (Fig. 4) is probably a relict of an original stratification, modified by sub-glacial deformation. The clast population is very varied. Some clasts are demonstrably of local origin, such as the quartzites derived from the West Falkland Group strata that underlie the tillite, but many of the granites, gneisses, schists and porphyrites are likely to be fartravelled, the proximity of the Proterozoic Cape Meredith Complex notwithstanding; limestone clasts (Fig. 4) are wholly exotic. Eastward there is a decrease in the mean and maximum clast dimensions, accompanied by localised intercalations of thinly bedded sandstone indicative of short-lived intervals of subaqueous sedimentation. The thickness in the Hill Cove area is about $850 \mathrm{~m}$, thence decreasing eastward across West Falkland to about $500 \mathrm{~m}$.

Farther east, on East Falkland, the character of the tillite is somewhat different. There, a more massive lithology prevails, with relatively sparse clasts randomly distributed in a coarse, gritty matrix (Figs 5 \& 6). At first this was thought of as a 'glaciomarine' till deposited beneath a floating ice sheet, but more recent opinion has shifted in favour of it originating as a largely terrestrial and subglacial till. Thickness is estimated at between 700 and $900 \mathrm{~m}$. Mean and maximum clast size are smaller than 
is the case in West Falkland and the range of clast lithologies seems more limited, with quartzite and granitic lithologies dominating and limestone a rare but important accessory.

The interest of the limestone clasts has been recently accentuated by the chance discovery within them of an Early Cambrian archaeocyath-trilobite fauna. The archaeocyaths are abundant and varied in some West Falkland clasts (Fig. 7) but are smaller and much rarer in East Falkland clasts. Archaeocyaths are not common in the Southern Hemisphere, with in situ faunas described only from Antarctica and Australia. The archaeocyaths found in limestone clasts from the Fitzroy Tillite Formation are of strongly Australo-Antarctic character, and a detailed taxonomic study has shown much overlap with the archaeocyath fauna described from the Transantarctic Mountains. That part of Antarctica seems the most likely source for the exotic clasts found in the Falkland Islands tillite. A very similar story has been known for some time from South Africa, where archaeocyathan limestone clasts in the Dwyka Group tillites have also been assigned a likely origin in the Transantarctic Mountains. Those reconstructions of Gondwana that place the Falkland Islands in close proximity to South Africa and East Antarctica would thus seem to be supported by the new fossil discoveries.

\section{The borehole programme}

From the late 1990s onwards there has been an upsurge in commercial interest in the offshore hydrocarbon potential around the Falkland Islands and a concomitant examination of the onshore mineral potential. An onshore exploration programme with gold mineralisation as the principal target culminated between 2005 and 2007 in an extensive borehole campaign (Figs 8 \& 9), and whilst the economic results were disappointing, an unexpected bonus was a series of core runs that fortuitously sampled the glacial to post-glacial succession in the central part of the East Falkland outcrop, to the ENE of Darwin (Fig. 1). The core runs include the top of the Fitzroy Tillite Formation and the succeeding strata at the base of the Port Sussex Formation, within which three members are recognised: in upward succession, the Hells Kitchen, Black Rock and Shepherds Brook members. The lower two of these three members record the deglaciation process, the 'icehouse to greenhouse' transition and the borehole cores allowed their detailed interpretation based on sedimentary logging, reflectance measurements and high-resolution, scanning XRF analyses.

For the main body of diamictite, the Fitzroy Tillite Formation, the observations from the borehole cores support a terrestrial origin as subglacial till, at least for the East Falkland outcrop. Important features are the absence of any signs of reworking by water movement, the random orientation of clasts, and the local development of glacitectonic structures. The latter included small-scale brecciation and fissility, planar shearing, and rotational deformation of fabrics around clasts. 
At the base of the Port Sussex Formation the Hells Kitchen Member is a 7 to $10 \mathrm{~m}$ thick unit comprising thinly interbedded and laminated mudstone, sandstone and diamictite with sporadic dropstones (Fig. 10); a sedimentological summary is provided in Table 1. This transitional succession was deposited during a fluctuating glacial regression that involved complex facies interaction arising from a range of depositional processes: meltwater, release of glacial debris from ice, gravity flows, iceberg calving and current reworking. It is an intermittent deglaciation sequence, followed in upward transition over about $2 \mathrm{~m}$ into the post-glacial mudstones of the Black Rock Member.

The mudstones forming the Black Rock Member may be either laminated and thinly bedded or massive, and can be either carbonaceous (the total organic carbon content is highly variable but reaches $40 \%$ locally) and pyritic or siliceous. Metabentonite laminae indicate contemporaneous volcanicity. Thickness estimates vary from about $125 \mathrm{~m}$ to $250 \mathrm{~m}$. Apart from a very sparse ichnofauna the mudstones are unfossiliferous and no identifiable microflora was recovered. The Black Rock Member accumulated under full post-glacial 'greenhouse' conditions, but whether the depositional environment was marine or lacustrine is uncertain. The latter alternative is preferred from the limited relevant evidence which includes the character of the trace fossil assemblage, and the presence of both a sparse non-marine bivalve fauna and a terrestrial (Glossopteris) flora in the Permian (Lafonia Group) strata that overlies the Port Sussex Formation (Fig. 2).

\section{Periodicity and age modelling}

Estimating the pace of the climatic transition represented by the Hells Kitchen Member can be assisted by a consideration of the likely effects of orbital forcing. It would seem highly probable that Late Palaeozoic climate change, like that of the Late Pleistocene, would have been modulated by a combination of Milankovitch orbital cyclicities with a strong 100 kyr component, although with a higher frequency obliquity component. Generation of a synthetic Permo-Carboniferous orbital solution incorporating $400 \mathrm{kyr}$ and 100 kyr eccentricity periods, a 35 kyr obliquity period and a 23 kyr precession period has provided a timeframe against which the fluctuations in the deglaciation sequence could be compared.

On the basis of potentially matching cycles in both detailed reflectance and XRF profiles (derived from scanning of cut core surfaces) and the synthetic orbital solution, a tentative age model has been achieved (Fig. 11). Further statistical analysis of the reflectance data (using wavelet power spectra) and high-resolution XRF logging results (first two principal components) strongly support the influence of 100 kyr and 400 kyr Milankovitch periodicities. The tentative time-scale modelled constrains the transition recorded by the Hells Kitchen Member to an interval spanning approximately 1.2 million years. Comparisons with the equivalent South 
African succession suggested that this time interval occurred within the Early Permian, Sakmarian Stage.

\section{Opportunities for future research}

We recognise the tentative nature of our results and interpretations but hope that they prove a stimulus to further investigations. The borehole cores recovered from the Falkland Islands are held by the British Geological Survey in the UK's National Geoscience Data Centre at Keyworth, Nottingham. Of the five core runs that sample all or part of the deglaciation transition only two have so far been subjected to detailed analysis, and all remain available for further study. Additional sedimentary logging would undoubtedly add to the understanding of depositional processes, and we would suggest that the following areas of investigation would aid the interpretation of the Early Permian 'icehouse to greenhouse' transition:

- The current age model largely depends on an assumption of uniform accumulation rates. This may be overly simplistic and affected by depth distortion. Detailed sedimentary analysis may resolve this issue.

- A range of element ratios was utilised, derived from XRF scanning of cut core surfaces. A different analytical approach and/or additional element data might enhance or modify the interpretation.

- Isotopic analysis using ${ }^{13} \mathrm{C}$ (and perhaps ${ }^{18} \mathrm{O}$ subject to diagenetic influences) may provide insight into ice volume, organic productivity and the marine or lacustrine environment; albeit this would be a destructive process.

- The absolute age of the succession remains poorly defined. Palynology has so far proved unsuccessful but may be worth repeating. The possibility of datable zircons within the bentonite horizons is untested.

\section{Acknowledgements}

Phil Stone contributes by permission of the Executive Director, British Geological Survey (NERC), and thanks the staff of the Department of Mineral Resources, Falkland Islands Government, for their support during the field programme. The borehole cores were made available through the cooperation of Falklands Gold and Minerals Ltd and the company's project manager, Derek Reeves; they were recovered to the UK with the help of the British Antarctic Survey. Analysis of the two core runs, by Kate Horan, was facilitated by the support of the academic and technical staff of the Department of Earth Sciences, University of Cambridge, with particular thanks due to Simon Crowhurst.

\section{Suggestions for further reading}


Aldiss, D.T. \& Edwards, E.J. 1999. The Geology of the Falkland Islands. British Geological Survey Technical Report WC/99/10. 135 pp. Available online at nora.nerc.ac.uk/507542/

Fielding, C. R., Frank, T. D. \& Isbell, J. L. 2008. The Late Palaeozoic ice age - a review of current understanding and synthesis of global climate patterns. Geological Society of America Special Paper, 441, pp.343-354.

Frakes, L. A. \& Crowell, J. C. 1967. Facies and paleogeography of Late Paleozoic Diamictite, Falkland Islands. Geological Society of America Bulletin, v.78, pp.37-58.

Horan, K. 2015. Falkland Islands (Islas Malvinas) in the Permo-Carboniferous From Icehouse to Greenhouse. Springer Earth System Sciences. 174 pp.

Stone, P. 2011. Borehole core recovered from the late Carboniferous to early Permian Fitzroy Tillite and Port Sussex formations, Falkland Islands: geological background and sample details. British Geological Survey Open Report, OR/11/028. 19 pp. Available online at nora.nerc.ac.uk/14415/

Stone, P. 2015. Geological exploration of South Atlantic islands and its contributions to the continental drift debate of the early $20^{\text {th }}$ century. Proceedings of the Geologists’ Association. v.126, pp.266-281.

Stone, P., Thomson, M. R. A. \& Rushton, A. W. A. 2012 (for 2011). An Early Cambrian archaeocyath-trilobite fauna in limestone erratics from the Upper Carboniferous Fitzroy Tillite Formation, Falkland Islands. Earth and Environmental Science Transactions of the Royal Society of Edinburgh. v.102, pp.201-225.

Trewin, N. H., Macdonald, D. I. M. \& Thomas, C. G. C. 2002. Stratigraphy and sedimentology of the Permian of the Falkland Islands: lithostratigraphic and palaeoenvironmental links with South Africa. Journal of the Geological Society, London, v.159, 5-19.

Figure Captions

Fig. 1 ... The Falkland Islands and their outline geology.

Fig. 2 ... A summary of Falkland Islands lithostratigraphy.

Fig. 3 ... Quartzite and granitic clasts in the Fitzroy Tillite Formation near Hill Cove, on the north coast of the West Falkland mainland to the north of Mount Adam. 
Fig. 4 ... A tillite section carrying a sub-horizontal fabric seen near Hill Cove, on the north coast of the West Falkland mainland to the north of Mount Adam. The hammer rests against a large clast of archaeocyathan limestone eroded from the cliff.

Fig. 5 ... The lithology of the Fitzroy Tillite Formation in East Falkland as seen in a quarried section about 7 km WSW of Fitzroy, East Falkland.

Fig. 6 ... The lithology of the Fitzroy Tillite Formation in East Falkland as seen in borehole cores recovered about $15 \mathrm{~km}$ ENE of Darwin, East Falkland. The core is 6.3 cm in diameter. BGS image P605058.

Fig. 7 ... Archaeocyaths in a thin section cut from a limestone clast recovered from the Fitzroy Tillite Formation near Hill Cove, on the north coast of the West Falkland mainland to the north of Mount Adam. The section is $45 \mathrm{~mm}$ wide. BGS image P537735.

Fig. 8 ... Mineral exploration drilling in progress about $15 \mathrm{~km}$ ENE of Darwin, East Falkland, in November 2005. BGS image P605052.

Fig. 9 ... Borehole core stacked at Goose Green, East Falkland, in February 2008, prior to the recovery of the ‘deglaciation’ core runs. BGS image P696267.

Fig. 10 ... Sections of borehole core illustrating characteristic lithologies of the Hells Kitchen Member as seen in borehole cores recovered about $15 \mathrm{~km}$ ENE of Darwin, East Falkland. The core is $4.5 \mathrm{~cm}$ in diameter. BGS image P696263.

Fig. 11 ... Preliminary age modelling showing some clustering of sedimentary cycles around possible Milankovitch Periods represented by the synthetic PermoCarboniferous orbital solution (ETP) which incorporates eccentricity, obliquity and precession forcing. Power units are reflectance ratios. The eccentricity units are normalised by adjustment of the units to a mean of zero and a standard deviation of one, and is the same procedure used to construct the ETP insolation sequence.

Table 1 ... A sedimentological interpretation of the Early Permian glacigenic deposits in the Falkland Islands. 


\begin{tabular}{|c|c|c|c|c|}
\hline $\begin{array}{l}\text { Facies } \\
\text { association }\end{array}$ & Lithologies & Sedimentology & $\begin{array}{l}\text { Depositional environment, characteristic } \\
\text { sedimentary processes }\end{array}$ & $\begin{array}{l}\text { Glacial Regime } \\
\text { and grounding line } \\
\text { proximity }\end{array}$ \\
\hline $\begin{array}{l}\text { Black Rock } \\
\text { Member, } \\
\text { Port Sussex } \\
\text { Formation }\end{array}$ & $\begin{array}{l}\text { Anoxic black } \\
\text { mudstones }\end{array}$ & $\begin{array}{l}\text { Lamination, dropstone- } \\
\text { free, rare borings. }\end{array}$ & Suspension settling, rare signs of bioturbation & $\begin{array}{l}\text { Glacial retreat and } \\
\text { development of } \\
\text { sediment-starved, } \\
\text { open-water } \\
\text { conditions }\end{array}$ \\
\hline \multirow[t]{2}{*}{$\begin{array}{l}\text { Hells } \\
\text { Kitchen } \\
\text { Member, } \\
\text { Port Sussex } \\
\text { Formation }\end{array}$} & $\begin{array}{l}\text { Mudrocks with } \\
\text { outsized } \\
\text { dispersed clasts }\end{array}$ & $\begin{array}{l}\text { Rhythmically } \\
\text { interstratified claystones } \\
\text { and siltstones with } \\
\text { dispersed gravel, } \\
\text { dropstones, deformed } \\
\text { bedding and microfaults. } \\
\text { Laminated mudstone with } \\
\text { dropstones and soft } \\
\text { sediment deformation } \\
\text { such as loading. }\end{array}$ & $\begin{array}{l}\text { Seasonal or other periodic influx of mixed } \\
\text { sediment from ice melt into a lake or marine } \\
\text { environment or suspension fallout from cyclic } \\
\text { meltwater pulses. Hydroplastic deformation } \\
\text { occurs through slumping and dewatering. } \\
\text { Some of the coarse material may be } \\
\text { destabilized glacigenic debris that accumulated } \\
\text { proglacially on a basin ramp and moved } \\
\text { downslope by mass-flow processes. } \\
\text { Influx of sediment into the lake or shallow sea } \\
\text { environment under strongly seasonal (varved) } \\
\text { or other periodic discharge, gravel indicates } \\
\text { ice-rafted debris. } \\
\text { Water-saturated and/or remobilised sediment } \\
\text { suggest rapid deposition. The fine sand and } \\
\text { mud were probably deposited by meltwater } \\
\text { plumes or waning turbidity currents in a sea or } \\
\text { lake floor setting, with coarse debris dropped } \\
\text { from floating ice (ice-rafted debris). Sand } \\
\text { aggregates may record fall of frozen sand } \\
\text { masses through the water column. }\end{array}$ & $\begin{array}{l}\text { Fluctuating ice- } \\
\text { proximal to ice- } \\
\text { distal environment } \\
\text { as floating ice-shelf } \\
\text { expands and } \\
\text { retreats. }\end{array}$ \\
\hline & Coarse ash tuff & $\begin{array}{l}\text { Granules in mudstone, no } \\
\text { grain size grading. }\end{array}$ & $\begin{array}{l}\text { Subaqueous pyroclastic fallout from a distant } \\
\text { volcanic source. }\end{array}$ & \\
\hline $\begin{array}{l}\text { Fitzroy } \\
\text { Tillite } \\
\text { Formation }\end{array}$ & $\begin{array}{l}\text { Glacial } \\
\text { diamictite }\end{array}$ & $\begin{array}{l}\text { Poorly sorted terrigenous } \\
\text { clastic sedimentary rock } \\
\text { with a wide range of grain } \\
\text { sizes, polymict } \\
\text { composition. }\end{array}$ & $\begin{array}{l}\text { Melt out and deformation of continental } \\
\text { subglacial lodgement till. }\end{array}$ & $\begin{array}{l}\text { Subglacial, non- } \\
\text { aqueous } \\
\text { environment. }\end{array}$ \\
\hline
\end{tabular}




\section{System/Period}

Ma

Lithostratigraphy

Principal lithologies

Depositional environments

\begin{tabular}{|c|c|c|c|c|}
\hline \multirow{2}{*}{ TRIASSIC } & \multirow{3}{*}{252 Deformation } & Bay of Harbours Fm (3000 m) & Sandstone, mudstone & Delta top and channels \\
\hline & & Brenton Loch Fm (3000 m) & Sandstone, laminated mudstone & Deltaic and prodeltaic basin floor \\
\hline PERMIAN & & Port Sussex Fm (400 m) & Mudstone, sandstone, diamictite & Glacial to marine or lacustrine \\
\hline \multirow{2}{*}{ CARBONIFEROUS } & & Fitzroy Tillite Fm (850 m) & Massive diamictite & Glacial \\
\hline & & Bluff Cove Fm $(250 \mathrm{~m})$ & Sandstone, mudstone & Shallow marine or proglacial deltaic \\
\hline \multirow{2}{*}{ DEVONIAN } & West & \multicolumn{3}{|c|}{ Low-angle disconformity } \\
\hline & Group & Port Stanley Fm (1100 m) & Quartz-sandstone, mudstone & Shallow marine and shoreface \\
\hline SILURIAN & 444 & Port Philomel Fm (350 m) & Sandstone, mudstone & Deltaic to shallow marine \\
\hline ORDOVICIAN & \multirow{2}{*}{486} & Fox Bay Fm (1500 m) & Micaceous sandstone, mudstone & Marine inner shelf and shoreface \\
\hline \multirow[t]{2}{*}{ CAMBRIAN } & & Port Stephens Fm (2500 m) & Quartzo-feldspathic sandstone & Fluvial to intertidal and shoreface \\
\hline & 540 & \multicolumn{3}{|c|}{ Major, angular unconformity } \\
\hline \multirow{3}{*}{ PROTEROZOIC } & c. 1000 & Cape Meredith Complex & \multicolumn{2}{|c|}{ Proterozoic granite and gneiss, c. $1000 \mathrm{Ma}$} \\
\hline & & & & E15160 \\
\hline & Lafonia Group & = Karoo Supergroup of South Africa & West Falkland Group = Cape Sup & Ip of South Africa \\
\hline
\end{tabular}




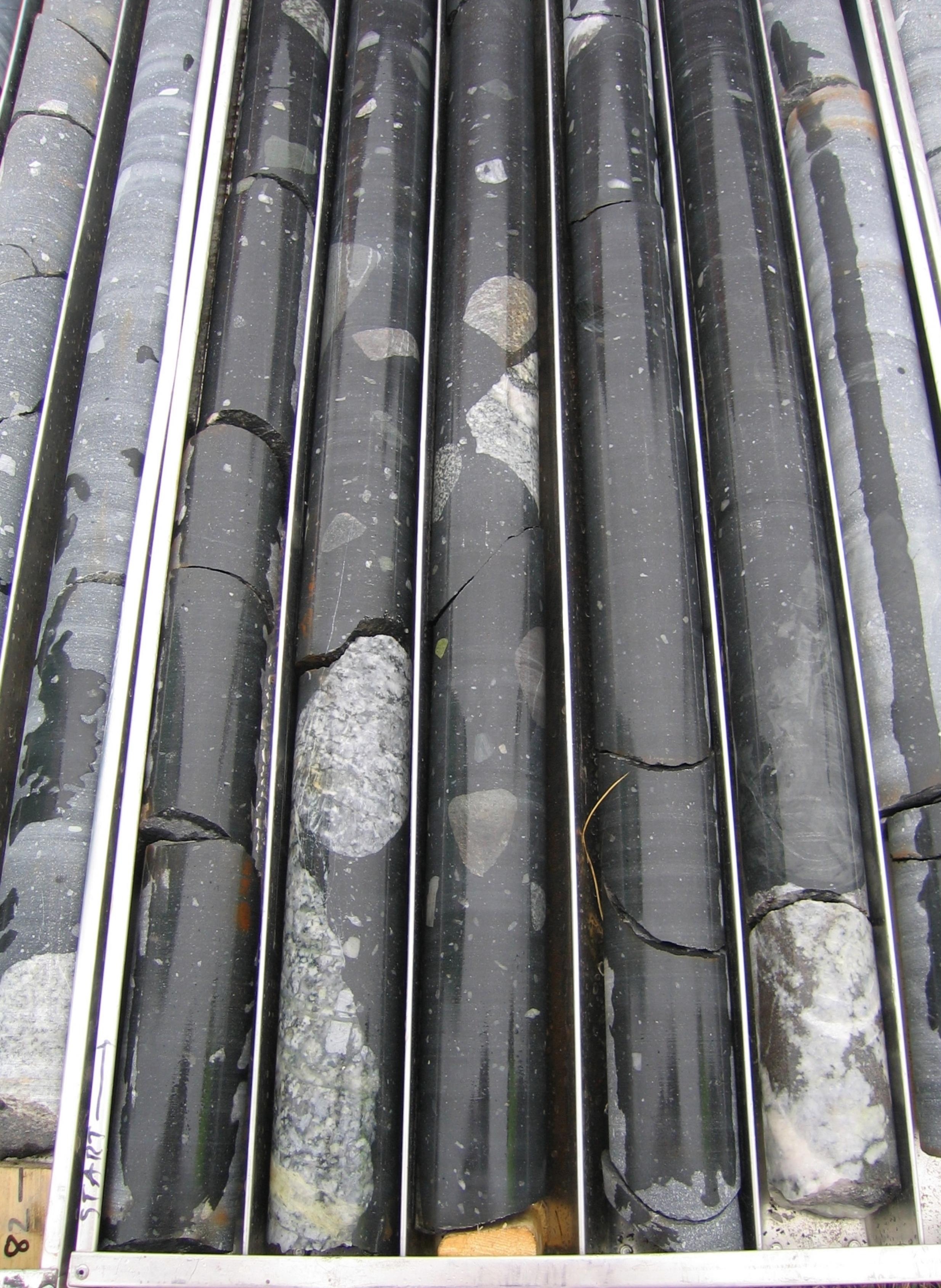




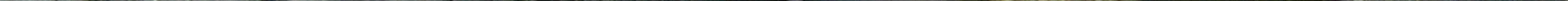




\section{Cring}

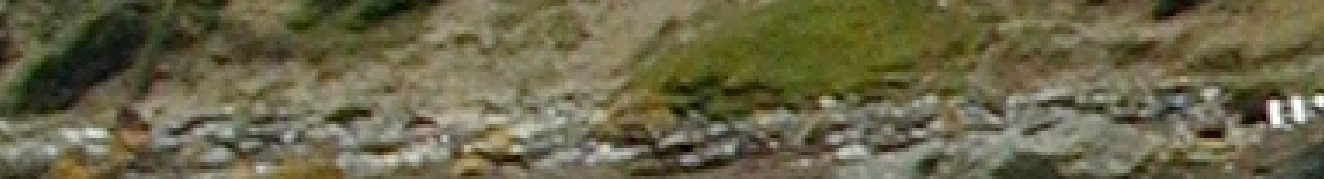

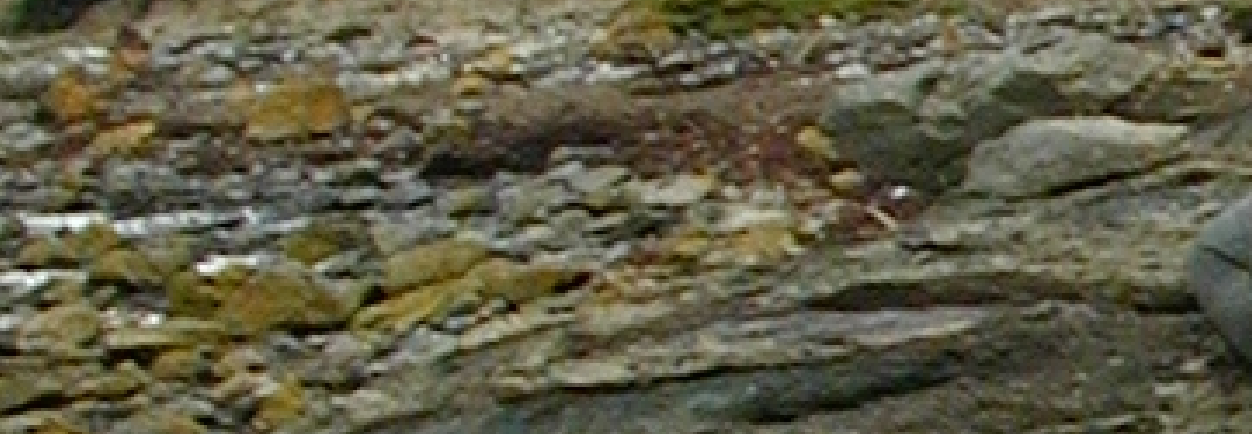

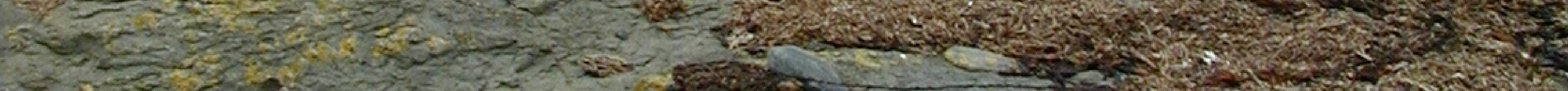

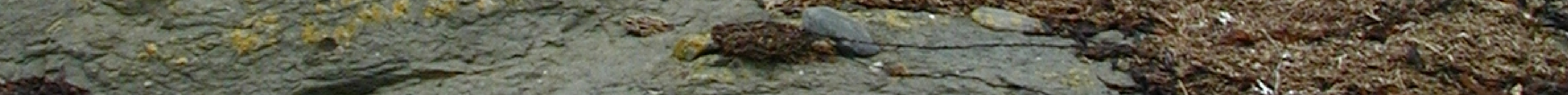
(5) $2 \cdot 2 \cdot, \cdot 0+2$ 


\section{(9015 50:}

4. $2 \mathrm{~m} \quad 1 \mathrm{~cm}$

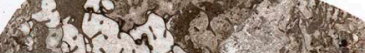

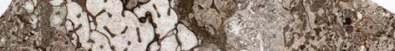

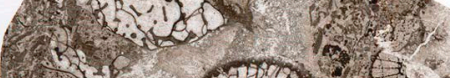

(1) 8

Cat $, 1,1$,

1.1.2.

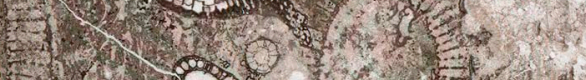

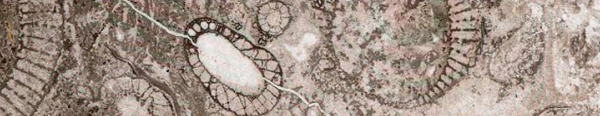

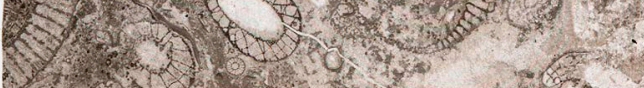

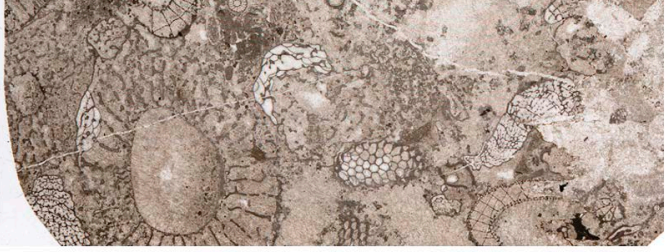

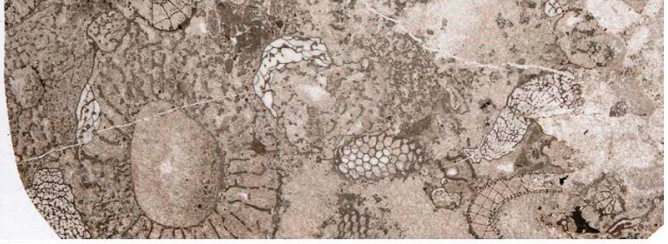




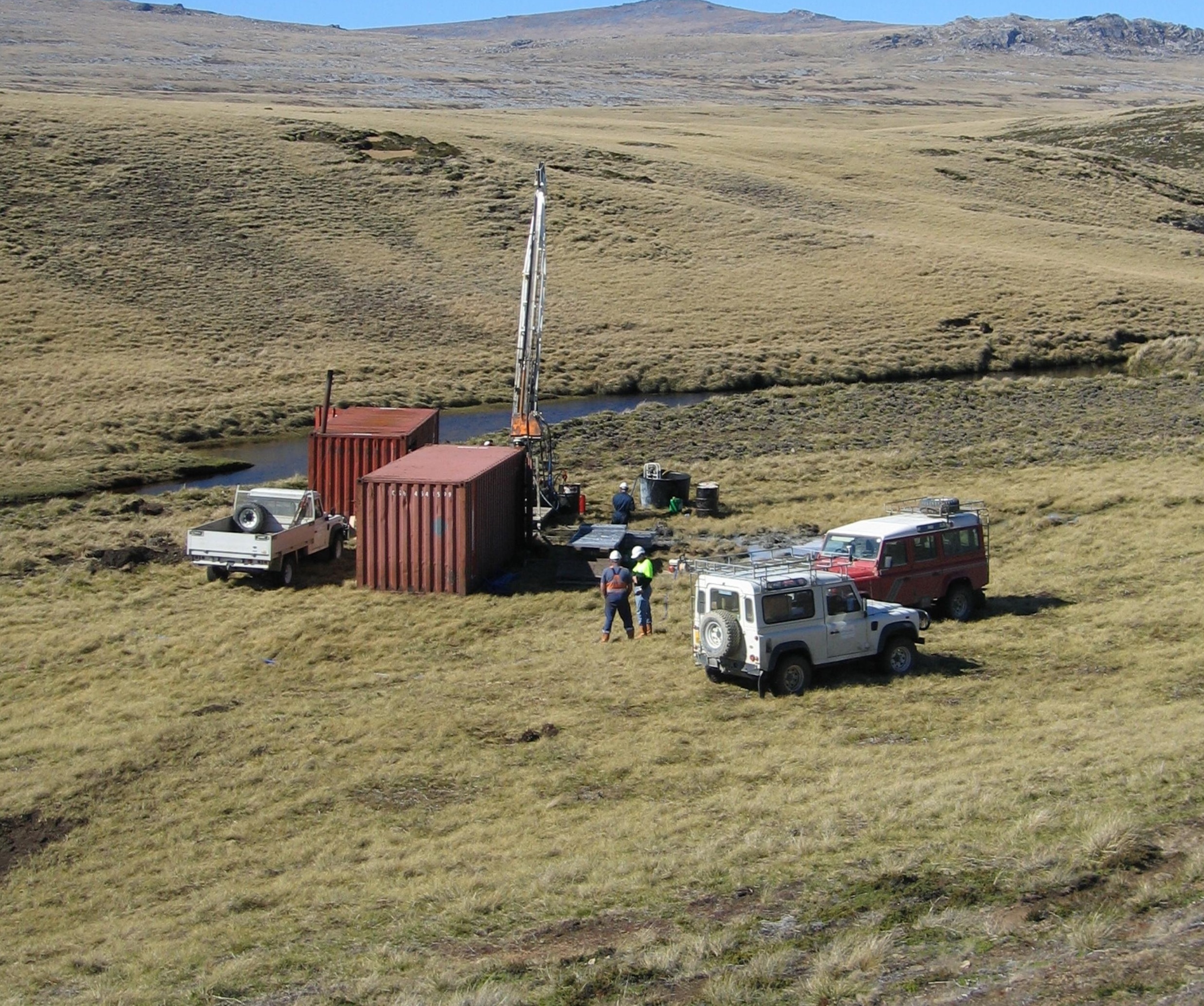




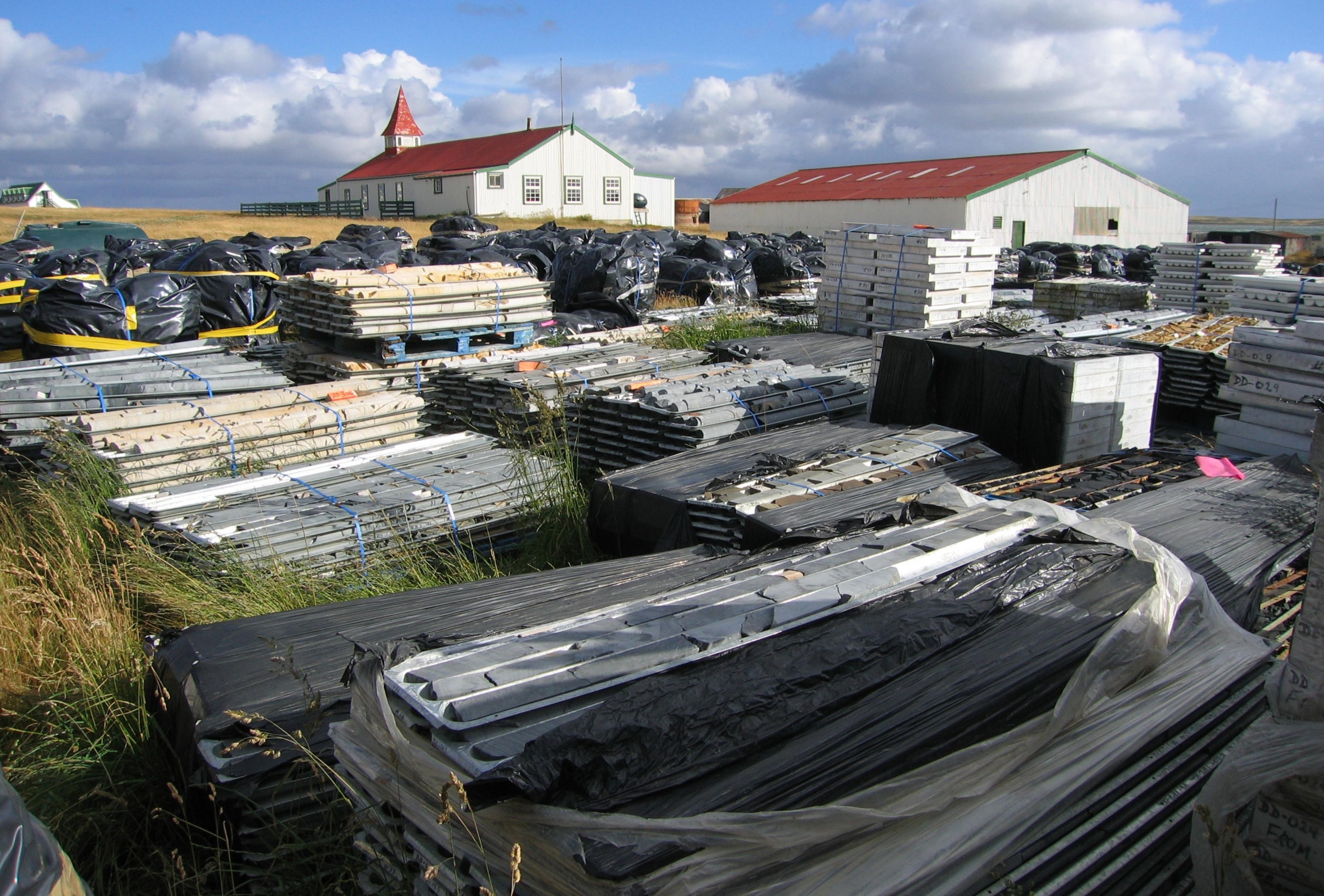





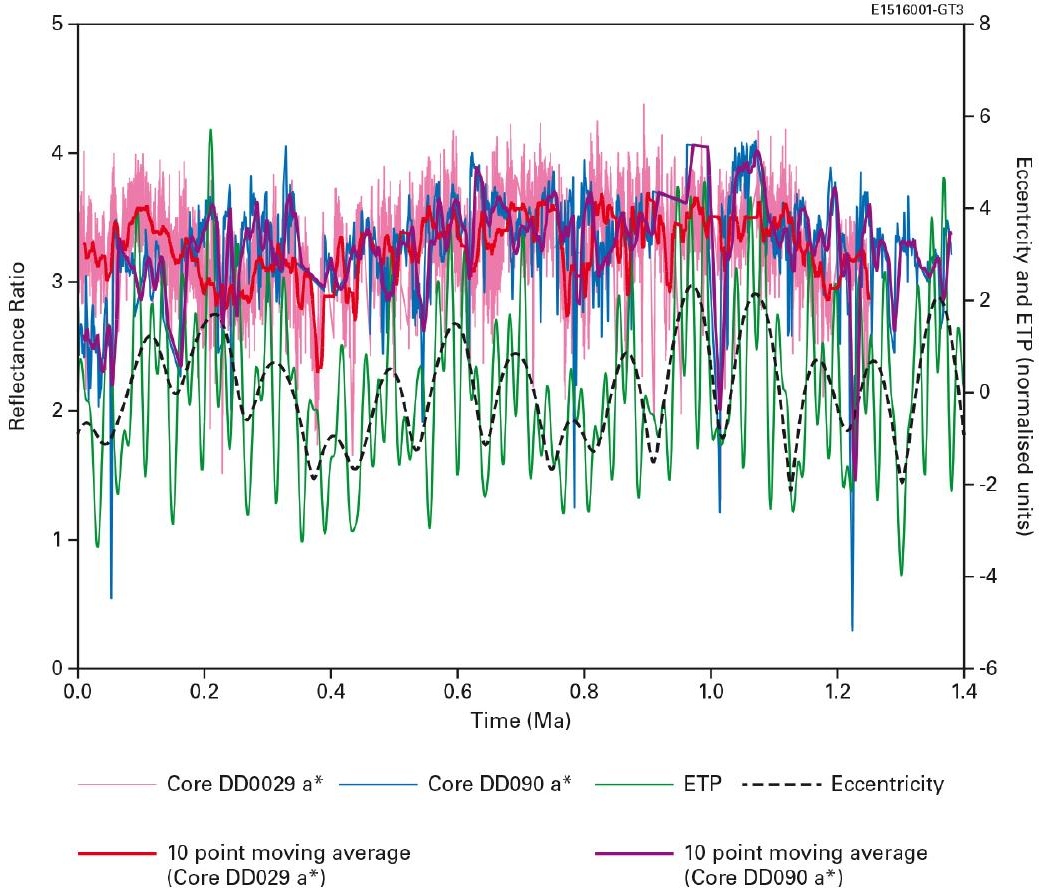

